\title{
Dealing With The Challenge Of Generating Employment In South Africa: Does Banking Sector Efficiency Matter?
}

Andrew Maredza, North-West University, South Africa

Sylvanus Ikhide, Stellenbosch University, South Africa

\begin{abstract}
In this paper, the authors seek to investigate the nexus between banking sector efficiency and labour employment in South Africa. The Hicks-Moorsteen aggregator functions were used to generate total factor productivity (TFP) efficiency measures for the big-four commercial banks. The authors then used the pooled estimation technique to examine the link between banking sector TFP efficiency and employment. First stage results revealed that the average banking sector TFP efficiency was 68 percent implying that the observed TFP was 32 percent short of the maximum TFP possible using the available technology. Hence, the banking sector has the potential to augment productivity by 32 percent without the need for further input utilisation if they were to operate efficiently.

Of paramount importance in the second stage analysis was that the authors found a positive and significant association between banking sector efficiency and national employment, meaning that national employment is influenced, inter alia, by the efficiency with which banks operate. This finding highlights how the enhancement of bank efficiency translates into increased employment in the economy. The authors therefore underscore the need for the banking sector to maintain high efficiency in order to augment efforts to achieve the objectives of the New Growth Path aimed at creating five million jobs in South Africa by 2020. They also advocate for banking sector policies and incentives that are directed at enhancing the efficiency of the banking sector.
\end{abstract}

Keywords: Bank Efficiency; Hicks-Moorsteen Index; Unemployment; Total Factor Productivity

\section{INTRODUCTION}

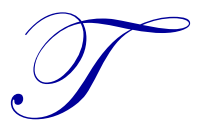

he banking system is considered as the economy`s lifeblood and a vital engine for growth in both developing and developed economies alike. Banks mainly facilitate the movement of funds from savers to borrowers. Thus, economic growth and development hinges strongly on the proper functioning of the banking system. STATSSA (2010) established that the financial services industry in South Africa was the third largest employer in the country during the second quarter of 2010, representing about 13.1 percent of total employment. Banks are dominant within the financial services industry. The banking sector acts as a catalyst for economic growth and, as such, holds great potential for employment creation through the transmission mechanism. An unstudied, but important, issue is whether changes in banking sector efficiency are reflected in national employment. In other words, does the enhancement of bank efficiency confer positive gains as far as South Africa`s employment generation is concerned?

Unemployment is one of the crucial challenges facing South Africa with the official unemployment rate currently at 25.2 percent and more than half of the young people unemployed. South Africa's unemployment rate remains high by local and international standards and evidently contributes toward much of the current social fragmentation and suffering experienced in South Africa. The 2011 annual budget highlighted unemployment as a problem which could have many adverse consequences if not curbed. National Treasury (2011, p. 17) identified enhancing "...efficiency across the economy" as one important job driver for accelerating growth and employment 
creation in achieving the targets of the New Growth Path. In a budget speech statement, Mr. Pravin (2013, p. 7), the Minister of Finance, also highlighted the need "to raise productivity and diversify the economy to create jobs and raise living standards." In this paper, the authors seek to unpack the relationship between banking sector efficiency improvement and employment and provide strategic and forward-looking lessons for the banking sector. This is crucial in order to inform formulation of suitable banking sector policies that are supportive of employment creation in line with the targets of South Africa`s New Growth Path. To the knowledge of the authors, this relationship has not been explored in the banking literature in South Africa the world over.

\section{OVERVIEW OF THE BANKING INDUSTRY IN SOUTH AFRICA}

Banking in South African is heavily concentrated within the so-called big-four banks which together account for more than 90 percent of the retail banking market (CGAP, 2011). The banking system assets constitute a substantial proportion of total output in most economies. The Banking Association South Africa (BASA, 2012) reported that the financial sector assets totalled over R6 trillion in 2012 with the banking sector accounting for over 50 percent. As such, banks are the most important institutions within the financial system. STATSSA (2011) reported that among the main contributors to the increase in economic activity of 2.9 percent in 2010, the financial services industry was ranked second with a contribution of 0.4 percent, along with other two industries that also contributed 0.4 percent. The Banking Association South Africa (BASA, 2012) also highlighted that the financial services industry contributed about 10.5 percent to GDP, 4 percent to employment, and that taxes from the financial services sector amounted to over 15 percent of GDP. In view of these facts, the need to examine the efficiency of banks and their impact to the economy cannot be overstated.

As can be seen in Figure 1, employment in the private sector, provided by the financial sector, increased from 100 percent in 2000 (base year) to 970.3 percent in 2008 before falling to 924.3 percent in 2009, and it declined further to 903.8 percent in 2010, likely reflecting the impact of the global financial crisis. Employment peaked up in 2011 and 2012 to 926.1 percent and 933.9 percent, respectively. However, the impact of the global financial crisis was evident when employment started to deteriorate in 2008 at the onset of the US sub-prime financial crisis.

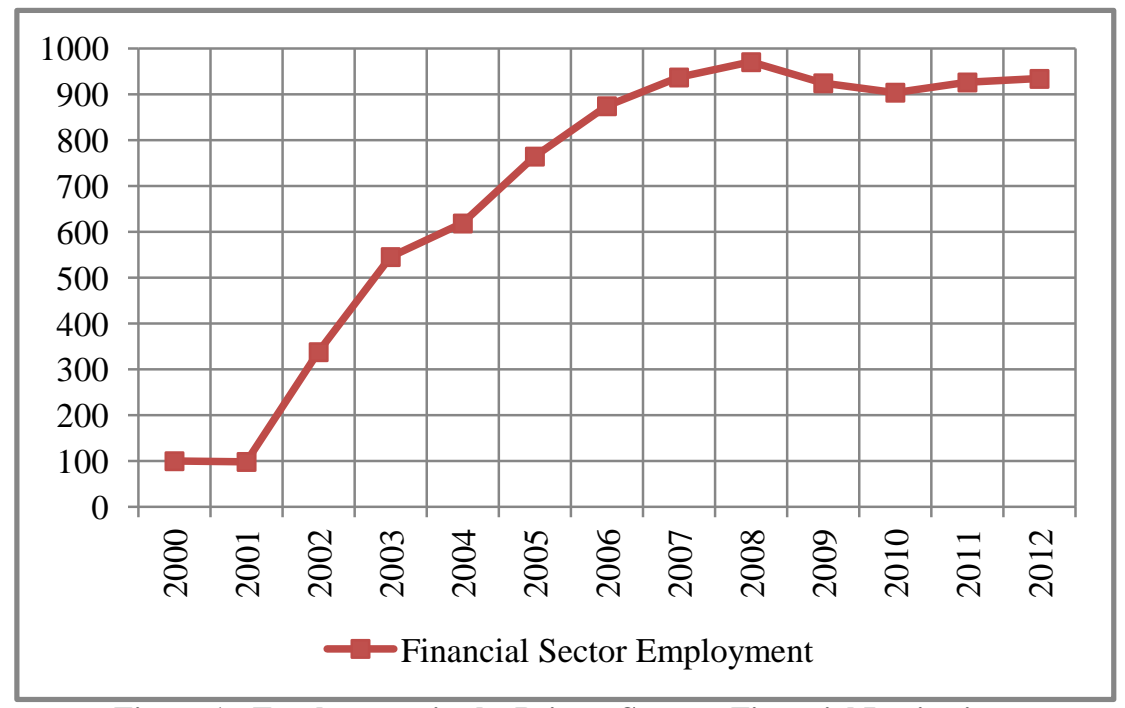

Figure 1: Employment in the Private Sector - Financial Institutions

Source: Author's Own Computation Using Data from SARB (www.resbank.co.za)

\section{LITERATURE REVIEW}

In this section of the study, a brief empirical literature review relating to efficiency and productivity of the banking sector is presented. This review is intended to show notable developments that have taken place in the area of banking efficiency and productivity in South Africa. The fundamental issue in this paper is to investigate the banking sector efficiency-employment nexus in South Africa for the eight-year period 2005-2012. 
Van der Westhuizen (2012) conducted a study in South Africa to shed light on whether a shift in the composition of a bank`s income from interest to non-interest income has any effect on the efficiency of a bank. One of the big-four banks was evaluated in 37 regions of South Africa and monthly data covering a two-year period were used. Two models were adopted based on whether the major income was interest or non-interest. The DPIN version 1.1, which uses the Data Envelopment Analysis (DEA) programs, was used to decompose the Hicks-Moorsteen TFP indexes. Models 1 and 2 were used to estimate the efficiency of the bank under the traditional (interest income) and non-traditional (non-interest income) function. His results showed that, on average, there were productivity gains as the bank moved from model 1 to model 2 suggesting that banks should concentrate on non-interest income as a major source of income.

In a recent study, Maredza and Ikhide (2013a) investigated the impact of the US sub-prime financial crisis on the efficiency and productivity of the South African commercial banking sector using a two-stage methodology framework for the period 2000-2010. The Hicks-Moorsteen total factor productivity (TFP) index approach developed by O'Donnell (2011), as opposed to the popular Malmquist TFP, was utilised. The DPIN version 3.0 software, which uses DEA programs, was utilised. Their first stage results showed that during the crisis period, there was a noticeable, but mild, deviation of total factor productivity and efficiency measures. However, their second stage analysis using the censored Tobit model showed that the financial crisis was the main determinant of bank efficiency, indicating that total factor productivity efficiency was 16.96 percent lower during the crisis period compared to the pre-crisis period. Their study found that the average TFP efficiency for the period 2000-2010 was 81.8 percent, implying that the banking sector fell short of 18.2 percent to realise the maximum productivity that was possible using the technology that was available.

In their study, Maredza and Ikhide (2013b) suggest that the banking sector (as represented by the big-four, which accounts for 90 percent of retail banking) has the potential to increase advances and loans by 18.2 percent without requiring additional input resources. At a macro-level, this would be expected to translate into increased household consumption or business investment and ultimately higher economic growth and eventually improved employment. Ikhide (2008) maintains that the basic benefit of enhanced efficiency, as indicated by a reduction in interest spreads (lending rate minus deposit rate), is an increased demand for loans for investment and greater mobilisation of savings through the banking system. As such, the authors hypothesise that enhancing banking sector efficiency has greater potential to increase investment and economic growth, thus contributing to higher employment.

Various other notable bank efficiency studies in South Africa include Okeahalam (2006), Ncube (2009), and Oberholzer (2010). Other studies (Okeahalam, 2001; Greenberg \& Simbanegavi, 2009; Mlambo and Ncube, 2011) have focused on examining bank performance and competition. While this concise literature review has shown some of the developments that have taken place in the South African banking industry, no study has taken a keen interest in exploring the nexus between banking sector efficiency and national employment. This particular paper is therefore intended to fill this gap in banking literature and attempt to articulate the relevance of our results for formulating bank policies that promote the generation of employment in South Africa.

\section{RESEARCH METHODOLOGY}

This study adopts a two-stage methodology framework. In the first stage, the DEA-based software program - Decomposing Productivity Index Numbers (DPIN version 3.0) developed by O`Donnell (2011) - was used to compute and decompose the Hicks-Moorsteen TFP indexes. The program analyses the drivers of productivity by decomposing changes in TFP into measures of technical change, technical efficiency change, scale efficiency change, and mix efficiency change (O`Donnell, 2011). A comprehensive understanding of this methodology is contained in the work of O'Donnell $(2010,2011)$. In the second stage, the relationship between bank efficiency and employment is investigated using panel data techniques.

To investigate the relationship between bank efficiency and employment in South Africa, the authors analysed a panel of four largest banks; namely, Absa bank, FirstRand bank, Nedbank and Standard bank for the period 2004 - 2012. The banking sector in South Africa is heavily concentrated within these so-called big-four banks which together represent more than 90 percent of the retail banking market. Data used in this study were 
collected from published annual reports of banks. Macro-time series data, such as the number of employed persons in South Africa and inflationary expectations were obtained from the quantec database.

The authors followed the intermediation approach in defining bank inputs and outputs. The intermediation approach acknowledges the intermediary role of banks as accepting deposits to produce bank outputs. Loans and advances, interest income, and non-interest income were considered outputs while deposits and current accounts, total operating expenses, non-performing loans and fixed assets were considered as input variables. Output variables were chosen to reflect both the traditional and non-traditional activities of modern banking. The authors treated nonperforming loans as inputs in line with Paradi et al (2004) who suggested that bad loans can either be treated as an output, but with an inverse value, or as an input where the lower the value the better. These variables are presented in Table 1.

Table 1: Variables Used in the First Stage DEA Analysis

\begin{tabular}{|l|c|}
\hline \multicolumn{1}{|c|}{ Variable } & Definition \\
\hline Outputs & Interest Income \\
\hline$Y_{1}$ & Non-interest Income \\
\hline$Y_{2}$ & Advances \& Loans \\
\hline$Y 3$ & Total Operating Expenses \\
\hline Inputs & Fixed Assets (Property and Equipment) \\
\hline $\mathrm{X}_{1}$ & Deposits and Current Accounts \\
\hline $\mathrm{X}_{2}$ & Non-performing loans \\
\hline $\mathrm{X}_{3}$ & \\
\hline $\mathrm{X}_{4}$ & \\
\hline
\end{tabular}

Panel data models were used for two main reasons. Firstly, panel data models takes into account firmspecific heterogeneity (individuality). Secondly, panel data overcomes the challenge of insufficient number of observations. Brooks (2008) states that through combing time-series and cross-sectional data, one can increase the number of degrees of freedom, and hence the power of the test. A number of panel data unit root tests were performed on the data. All the tests produced stationary variables in levels and the results are presented in Table 2.

Table 2: Panel Data Unit Root Tests

\begin{tabular}{|l|c|c|}
\hline \multicolumn{1}{|c|}{ Tests } & Statistic & P-value \\
\hline \multicolumn{1}{|c|}{ Null Hypothesis } & Each Individual Time Series Contains A Unit Root \\
\hline Levin, Lin, Chu (LLC) & -7.36771 & $0.0000^{* * *}$ \\
\hline Im, Pesaran \& Shin (IPS) & -4.31571 & $0.0000^{* * *}$ \\
\hline ADF - Fisher Chi-square & 76.8673 & $0.0000^{* * *}$ \\
\hline PP - Fisher Chi-square & 92.1298 & $0.0000^{* * *}$ \\
\hline
\end{tabular}

$* /[* *] /(* * *)$ denotes significance at $10 \%, /[5 \%] /(1 \%)$ level of significance, respectively.

The authors then estimated the following log-linear model:

$\operatorname{LnLAB}_{t}=\alpha_{i t}+\beta_{1} \operatorname{LnTFPE}_{i t}+\beta_{2} \operatorname{LnTECH}_{i t}+\beta_{3} \operatorname{LnINFL}_{t}+\mu_{i t}$

where:

$L n \mathrm{LAB}_{t} \quad$ - The number of South African persons employed in period $t$

$L n \mathrm{TFPE}_{i t} \quad$ - Total factor productivity efficiency score for bank $i$ in period $t$

$L n \mathrm{TECH}_{i t} \quad$ - Technological progress for bank $i$ in period $t$

$L_{n} \mathrm{INFL}_{t} \quad$ - Consumer price index inflation expectations in period $t$

$\mu_{\mathrm{it}} \quad-\quad$ Error term to capture other possible factors not specified

\subsection{Labour Employment}

The logarithm of the number of persons employed in South Africa was used to capture the level of employment. This variable is hypothesised to be influenced by the right-hand variables, such as banking sector efficiency, technological progress and inflation expectations of consumers.

1364 Copyright by author(s) Creative Commons License CC-BY

2013 The Clute Institute 


\subsection{Total Factor Productivity Efficiency (TFPE)}

The logarithm of TFP efficiency was used. This efficiency variable, which constitutes the main focus of this paper, is generated in the first stage using the Hicks-Moorsteen total factor productivity (TFP) index approach. The authors expect the effect of bank sector efficiency on employment to be positive. This follows from the argument that enhanced efficiency implies achieving more with less input resources. These gains are then passed on to recipients of banking services through affordable services, easy access to banking services, thereby increasing investment, economic activity and employment in the process.

\subsection{Technological Progress}

The inclusion of the technological variable computed in the first stage analysis of efficiency and productivity is important as it could have a significant positive effect on the level of employment. The authors took the logarithm of $\Delta$ Tech which is also generated in the first stage as a proxy for technological progress. They are expecting technological progress to have a positive impact on employment.

\subsection{Inflationary Expectations}

The logarithm of consumer inflation expectations was included to acknowledge the role and importance of inflationary expectations on employment in South Africa. According to the Phillips curve theory, there is a trade-off between inflation and unemployment. Hence, a positive sign is expected between inflation expectations and employment.

\section{DISCUSSION OF RESULTS}

At this juncture, the authors highlight the fact that these big four banks are a fair representation of the entire banking sector. In 2010, the big-four contributed 84.6 percent to the balance-sheet size of the total banking sector (SARB, 2010). CGAP (2011) also states that together the big-four represents over 90 percent of the total retail banking market in South Africa. Hence, the results of this paper can be interpreted as being representative of the total banking sector. It is important to recall that efficiency scores range from zero to one. A score below one represents an inefficient bank located below the production frontier, while a score of one implies that the bank is fully efficient and lies on the frontier of the production technology. Regarding productivity, a value greater than one indicates positive TFP growth from period $t$ to period $t+1$.

Total factor productivity efficiency (TFPE) and $\triangle T E C H$ for technological progress will be used later in the second stage analysis, inter alia, as determinant factors of employment. However, our main variable of focus is the TFP efficiency, which is a measure of overall productive performance. TFP efficiency measures the discrepancy between the observed TFP and the maximum TFP possible using the available technology (O`Donnell, 2010). Table 5 (see Appendix) indicates that this measure was an average of 67.8 percent, which means that for the period 20052012, banks fell short of 32.2 percent to realise the maximum total factor productivity that was possible using the available technology. There was, however, a noticeable change in the TFPE scores for the period 2007-2008 which largely accounts for the low average of TFP efficiency obtained. This period coincides with the worst performance noted during 2007-2009 when economies were at the height of the financial global crisis. This worst performance is evident across all the different efficiency and productivity scores presented in the Appendix. Maredza and Ikhide (2013b) found that the financial crisis impact was the main determinant of banking efficiency and productivity in South Africa with TFP efficiency lower by $16.96 \%$ during and after the crisis period compared to the pre-crisis period. Levels of productivity and the several input- and output-oriented efficiency scores for all banks for the eightyear period are presented in Table 5, while Table 6 (see Appendix) reports indexes measuring changes in total factor productivity $(\triangle T F P)$.

The average TFP efficiency score obtained in this study is lower than that obtained in the study of Maredza and Ikhide (2013), largely on account of the difference in the definition of bank output variables. While their study considered only loans and advances as the only bank output, our study included interest income, non-interest income, and loans and advances. Hence, our study has included all important variables that reflect traditional and non-traditional activities of modern banking. Maredza (2012) sounds a word of caution that when making 
comparative analysis, one should be conscious of the fact that DEA is sensitive to the definition of variables used and that efficiency scores are time specific and therefore change over time, making the results relevant only at the point in time when the study was conducted.

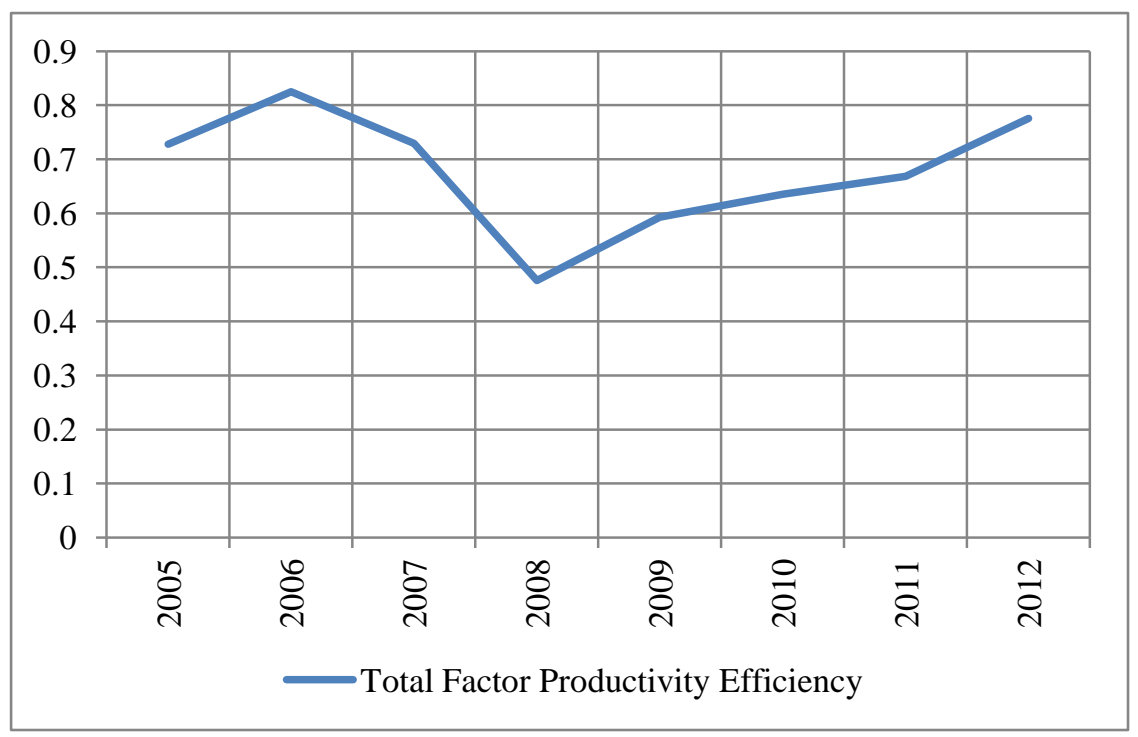

Figure 2: Total Factor Productivity Efficiency (TFPE)

In the second stage, three techniques of panel data analysis were considered and estimation results for the pooled, fixed effects and random effects models are presented in tabular form in Table 3. In order to correct for the presence of heteroscedasticity, white diagonal standard errors and covariances were used. After performing various relevant poolability tests, the pooled model, which assumes cross-section homogeneity, was finally considered. A significant F-test for individual fixed effects failed to reject that cross sections are homogeneous, implying that bank-specific fixed effects could not be accounted for in our specification. The pooled model emphasises the joint estimation of coefficients and, as such, can increase degrees of freedom, potentially lowering standard errors on the coefficients (Baltagi, 2008). All explanatory variables included in the model are highly significant. The F-statistic depicted in Table 3, shows that the explanatory variables are jointly significant in explaining the dependent variable, which is employment. A comparison of the adjusted $\mathrm{R}^{2}$ indicates a high value of 0.8095 for the pooled model and confirms it to be our most robust and representative model specification. Gujarati (2004) sounds a word of caution that pooled models normally suffer the problem of serial correlation. However, in our study as supported by a Durbin Watson statistic of 1.8956 , serial correlation did not prove to be a problem.

Table 3: Employment (2005-2012)

\begin{tabular}{|l|c|c|c|}
\hline \multicolumn{1}{|c|}{ Pependant Variable } & \multicolumn{2}{c|}{ Random Effects } \\
\hline \multirow{2}{*}{ Constant } & $7.07477^{* * *}$ & Employment & $7.07477^{* * *}$ \\
& $(0.0000)$ & - & $(0.0000)$ \\
\hline \multirow{2}{*}{ TFP Efficiency } & $0.00831^{* * *}$ & $0.01399^{* * *}$ & $0.00831^{* * *}$ \\
& $(0.0398)$ & $(0.0129)$ & $(0.0398)$ \\
\hline \multirow{2}{*}{ Technological Progress } & $0.0223^{* * *}$ & $0.0231^{* * *}$ & $0.02225^{* * *}$ \\
& $(0.0001)$ & $(0.0005)$ & $(0.0001)$ \\
\hline \multirow{2}{*}{ Inflation Expectations } & $0.06831^{* * *}$ & $0.07164^{* * *}$ & $0.06831^{* * *}$ \\
& $(0.0000)$ & $(0.0000)$ & $(0.0000)$ \\
\hline Adjusted $R^{2}$ & 0.8095 & 0.8048 & 0.8095 \\
Durbin Watson & 1.8956 & 1.9923 & 1.8956 \\
\hline
\end{tabular}

P-values are reported in parentheses. */[**]/ $(* * *)$ denotes significance at 10\%, / [5\%]/ (1\%) level of significance respectively.

In panel data, a fixed effects model (FEM) is relevant where the researcher intends to study the extent of firm heterogeneity and to examine any particular firms of interest (Griffiths et al, 2008). Gujarati and Porter (2009) 
state these FEMs capture the different special features of each firm, such as managerial style or the type of market each firm is serving. However, if the firms under study are homogenous, one can then use a pooled regression model. As shown in Table 4, our pooled vs. fixed effects F-tests failed to reject the null hypothesis that cross sections are homogenous, implying that bank-specific fixed effects are not valid in this particular study. Baltagi (2008) maintains that the random effects model (REM) is appropriate if draws are made randomly from a large population where $N$ is generally large. In this study, $N=4<T=8$ was not sufficiently large to permit the use of the random effects model. The authors therefore concluded that individual random effects were not valid. Gujarati $(2004,648)$ states that if the cross-section or individual-specific error component is zero, there will be no difference between the pooled and the random effects model in which case one would simply run a pooled regression.

Table 4: Diagnostics Tests

\begin{tabular}{|c|c|c|c|}
\hline Test & Test Statistic & Critical Value & Inference \\
\hline $\begin{array}{l}\text { Pooled vs. Individual (cross sectional): } \\
H_{0}: \mu_{1}=\mu_{2}=\ldots=\mu_{N-1}=0 \\
H_{A}: \text { Not all equal to } 0\end{array}$ & $F=0.77893$ & $\mathrm{~F}_{3,25,0.05}=2.991$ & $\begin{array}{c}\text { The authors failed to reject } H_{0} \\
\text { implying that cross sections } \\
\text { are homogenous. Hence, } \\
\text { individual effects are not } \\
\text { valid. }\end{array}$ \\
\hline $\begin{array}{l}\text { Heteroscedasticity: } \\
H_{0}: \sigma_{i}^{2}=\sigma \text { (homoscedastic errors) } \\
H_{A}: \text { Not equal for all } i \text { (heteroscedastic errors) }\end{array}$ & \multicolumn{3}{|c|}{$\begin{array}{l}\text { White cross-section standard errors and covariances were used to correct } \\
\text { the problem of heteroscedasticity. }\end{array}$} \\
\hline $\begin{array}{l}\text { Serial Correlation: } \\
H_{0}: \rho=0\left(\mu_{i} \text { are fixed parameters }\right) \\
H_{A}: \rho \neq 0\end{array}$ & $\mathrm{D}_{\mathrm{P}}=1.8955$ & $\begin{array}{c}\text { No correlation if: } \\
\mathrm{D}_{\mathrm{PL}}<\mathrm{D}_{\mathrm{P}}<4-\mathrm{D}_{\mathrm{PU}} \\
1.8421<\mathrm{D}_{\mathrm{P}}<2.1312\end{array}$ & $\begin{array}{c}\text { The authors conclude that no } \\
\text { serial correlation was present } \\
\text { in the model. }\end{array}$ \\
\hline
\end{tabular}

The coefficient on technological progress was positive and significant as expected, implying that advances in banking technology are associated with higher national employment. The coefficient on inflation expectations was also significant with a positive sign in line with our expected priori based on the Philips curve theory. Of paramount value to the present study was to establish the significance and magnitude of the impact of gains in banking sector efficiency on national employment. A positive and significant coefficient found implies that employment is indeed influenced by the efficiency with which banks operate. However, the size of the incremental effect appears to be marginal. On average, a 1 percent increase in bank efficiency stimulates an increase of employment by 0.0083 percent. This reported positive impact of bank efficiency is in line with our earlier expectation. The authors therefore underscore the need for the banking sector to maintain high efficiency in order to augment efforts to achieve the objectives of the New Growth Path aimed at creating five million jobs in South Africa by 2020. They also advocate for banking sector policies and incentives that are directed at enhancing the efficiency of the banking sector.

\section{CONCLUSION}

In this paper, the authors evaluated the total factor productivity and efficiency of the four largest South African banks for the period 2003-2012. The measurement and the decomposition of total factor productivity into several measures of efficiency was performed using the software program DPIN 3 developed by O'Donnell (2011). The main motivation driving this research has been to explore the nexus between gains in bank efficiency and employment. In order to study this relationship, the authors applied panel data techniques, in particular the pooled model. Our findings confirmed a positive and significant relationship between bank efficiency and employment. Hence there is indeed evidence that improvement in the banking sector efficiency transmit through to increased employment in the economy. Therefore, there is need for further studies to investigate the possible transmission mechanisms by which changes in bank efficiency feeds through to increased employment in the economy. To the best of our knowledge, this is the first study to explore the banking sector efficiency-employment nexus in South Africa. 


\section{AUTHOR INFORMATION}

Mr Andrew Maredza is a lecturer in the School of Economic \& Decision Sciences at North-West University. He is currently a PhD candidate of the University of Fort Hare, South Africa. His current research focus is financial inclusion, efficiency and productivity analysis within the context of banking. School of Economics \& Decision Sciences, Private Bag X2046, Mmabatho, 2735, South Africa. Tel: +27 (0)18 389 2810. E-mail: Andrew.Maredza@nwu.ac.za (Corresponding author)

Professor Sylvanus Ikhide is a Professor at the University of Stellenbosch, Business School, South Africa. He is currently supervising my doctoral studies in the area of banking, productivity and efficiency. E-mail: Sylvanus.Ikhide@usb.ac.za

\section{REFERENCES}

1. $\quad$ Baltagi, B. (2008). Panel Data Econometrics, $4^{\text {th }}$ Edition. Chichester: John Wiley and Sons.

2. Banking Association South Africa (BASA) (2012). 2012 South African Banking Sector Overview. (Accessed 2013 February 24) Retrieved from http://www.banking.org.za/index.php/our-industry/2012south-african-banking-sector-overview/

3. Brooks, C. (2008). Introductory Econometrics for Finance, $2^{\text {nd }}$ Edition. Cambridge, New York: Cambridge University Press.

4. Consultative Group Against Poverty (CGAP). (2011). Technology Program Country Note, South Africa. (Accessed 2013 May 7) Retrieved from http://www.cgap.org/publications/technology-program-countrynote-south-africa

5. Greenberg, J.B., \& Simbanegavi, W. (2009). Testing for Competition in the South African Banking Sector, Faculty of Commerce University of Cape Town. 4 November.

6. Gujarati, D.N., \& Porter, D.C. (2009). Basic Econometrics. $5^{\text {th }}$ Edition. New York: McGraw-Hill.

7. Gujarati, D. (2004). Basic Econometrics. $4^{\text {th }}$ Edition. New York: McGraw-Hill.

8. Ikhide, S.I. (2008). Measuring the Operational Efficiency of Commercial Banks in Namibia, South Africa Journal of Economics, 76(4), 586 - 595.

9. Maredza, A., \& Ikhide, S. (2013a). The Impact of the Global Financial Crisis on Efficiency and Productivity of the Banking System in South Africa, Economic Research Southern Africa, ERSA Working Paper Series No 328.

10. Maredza, A., \& Ikhide, S. (2013b). Measuring the Impact of the Global Financial Crisis on Efficiency and Productivity of the Banking System in South Africa, Mediterranean Journal of Social Sciences. Vol. 4(6), $553-568$.

11. Maredza, A., (2012). Are For-Profit Hospitals More Efficient than Non-Profit Hospitals? A Case Study of Zimbabwe using Data Envelopment Analysis and the Tobit Model, African Journal of Business Management, Vol. 6(47), 11670 - 11682.

12. Mlambo, K., \& Ncube, M. (2011). Competition and Efficiency in the Banking Sector in South Africa, African Development Review, 23(1), 4-15.

13. National Treasury. (2011). Economic Policy and Outlook. Available [Online] Retrieved from http://www.treasury.gov.za/documents/national\%20budget/2011/review/chapter\%202.pdf

14. Ncube, M. (2009). Efficiency of the Banking Sector in South Africa, Paper presented at the Fourth African Economic Conference 2009 on Fostering Development in an Era of Financial and Economic Crises, 11-13 November 2009, Addis Ababa, Ethiopia.

15. Oberholzer, M., Van Der Westhuizen, G., \& Van Rooyen, S. (2010). The Influence of Banks' Internal Performance on Market Performance: A Non-parametric Approach, Southern African Business Review. 14(2), $65-88$.

16. O'Donnell, C.J. (2010). DPIN version 1.0: A Program for Decomposing Productivity Index Numbers, working paper, Centre for Efficiency and Productivity Analysis, University of Queensland.

17. O'Donnell, C.J. (2011). DPIN Version 3.0: A Program for Decomposing Productivity Index Numbers. Centre for Efficiency and Productivity Analysis Working Papers, University of Queensland.

18. Okeahalam, C.C. (2001). Structure and Conduct in the Commercial Banking Sector of South Africa. Presented at TIPS 2001 Annual Forum. 
19. Okeahalam, C.C. (2006). Production Efficiency in the South African Banking Sector: A Stochastic Analysis, International Review of Applied Economics, 20(1), 103 - 123.

20. Paradi, J.C., Yang Z., \& Zhu, H. (2004). Assessing Bank and Bank Branch Performance. In: Cooper, W.W., SEIFORD, L.M., and ZHU, J., eds. (2011). Handbook on Data Envelopment Analysis, International Series in Operations Research \& Management Science 164, New York: Springer Science + Business Media. Ch 13.

21. Pravin, G. (2013). 2013 Budget Speech, Department of National Treasury, Pretoria: South Africa. 27 February 2013.

22. South African Reserve Bank. (SARB) (2010). Annual Report 2010, Bank Supervision Department, $90^{\text {th }}$ Anniversary. Retrieved from http://www.reservebank.co.za/

23. Statistics South Africa (STATSSA). (2010). Quarterly Labour Force Survey, Quarter 2. Retrieved from http://www.statssa.gov.za/publications/P0211/P02112ndQuarter2010.pdf.

24. Van Der Westhuizen, G. (2012). Change in the Composition of Bank Income and Its Effect on the Changes in the Efficiency of Bank Regions, International Business \& Economics Research Journal, 11(6), 631 646. 


\section{APPENDIX}

Table 5: Levels of Productivity and Efficiency

\begin{tabular}{|c|c|c|c|c|c|c|c|c|c|c|c|c|c|c|}
\hline \multicolumn{15}{|c|}{ Levels Computed Using Hicks-Moorsteen Aggregator Functions } \\
\hline Period & TFP & TFP* & TFPE & OTE & OSE & OME & ROSE & OSME & ITE & ISE & IME & RISE & ISME & RME \\
\hline 2005 & 1.4375 & 1.9309 & 0.7444 & 1 & 1 & 1 & 0.7444 & 0.7444 & 1 & 1 & 1 & 0.7444 & 0.7444 & 0.7444 \\
\hline 2005 & 1.1297 & 1.5192 & 0.7436 & 1 & 1 & 1 & 0.7436 & 0.7436 & 1 & 1 & 0.9908 & 0.7505 & 0.7436 & 0.7436 \\
\hline 2005 & 1.199 & 1.831 & 0.6548 & 1 & 1 & 1 & 0.6548 & 0.6548 & 1 & 1 & 0.8898 & 0.7359 & 0.6548 & 0.6548 \\
\hline 2005 & 1.1838 & 1.5414 & 0.768 & 1 & 1 & 1 & 0.768 & 0.768 & 1 & 1 & 1 & 0.768 & 0.768 & 0.768 \\
\hline 2006 & 1.263 & 1.4056 & 0.8986 & 1 & 1 & 1 & 0.8986 & 0.8986 & 1 & 1 & 1 & 0.8986 & 0.8986 & 0.8986 \\
\hline 2006 & 1.2337 & 1.3764 & 0.8963 & 1 & 1 & 1 & 0.8963 & 0.8963 & 1 & 1 & 1 & 0.8963 & 0.8963 & 0.8963 \\
\hline 2006 & 1.1164 & 1.5644 & 0.7136 & 1 & 0.9666 & 1 & 0.7136 & 0.7136 & 1 & 0.9666 & 1 & 0.7136 & 0.7136 & 0.7383 \\
\hline 2006 & 1.2282 & 1.5547 & 0.79 & 1 & 1 & 1 & 0.79 & 0.79 & 1 & 1 & 1 & 0.79 & 0.79 & 0.79 \\
\hline 2007 & 1.1658 & 1.4077 & 0.8282 & 1 & 1 & 1 & 0.8282 & 0.8282 & 1 & 1 & 1 & 0.8282 & 0.8282 & 0.8282 \\
\hline 2007 & 1.3669 & 1.7835 & 0.7664 & 1 & 1 & 1 & 0.7664 & 0.7664 & 1 & 1 & 1 & 0.7664 & 0.7664 & 0.7664 \\
\hline 2007 & 1.1809 & 1.6404 & 0.7199 & 1 & 1 & 1 & 0.7199 & 0.7199 & 1 & 1 & 1 & 0.7199 & 0.7199 & 0.7199 \\
\hline 2007 & 1.2216 & 2.0283 & 0.6023 & 1 & 1 & 1 & 0.6023 & 0.6023 & 1 & 1 & 1 & 0.6023 & 0.6023 & 0.6023 \\
\hline 2008 & 1.2562 & 1.4765 & 0.8508 & 1 & 1 & 1 & 0.8508 & 0.8508 & 1 & 1 & 1 & 0.8508 & 0.8508 & 0.8508 \\
\hline 2008 & 1.3577 & 3.8767 & 0.3502 & 1 & 1 & 1 & 0.3502 & 0.3502 & 1 & 1 & 1 & 0.3502 & 0.3502 & 0.3502 \\
\hline 2008 & 1.2837 & 2.3597 & 0.544 & 1 & 1 & 1 & 0.544 & 0.544 & 1 & 1 & 1 & 0.544 & 0.544 & 0.544 \\
\hline 2008 & 1.9118 & 12.007 & 0.1592 & 1 & 1 & 1 & 0.1592 & 0.1592 & 1 & 1 & 1 & 0.1592 & 0.1592 & 0.1592 \\
\hline 2009 & 1.3368 & 1.7437 & 0.7666 & 1 & 1 & 1 & 0.7666 & 0.7666 & 1 & 1 & 1 & 0.7666 & 0.7666 & 0.7666 \\
\hline 2009 & 1.1401 & 1.4618 & 0.7799 & 0.9913 & 0.9447 & 0.9796 & 0.8032 & 0.7868 & 0.9583 & 0.9772 & 0.8953 & 0.9091 & 0.8139 & 0.8329 \\
\hline 2009 & 1.2455 & 1.9133 & 0.651 & 1 & 1 & 1 & 0.651 & 0.651 & 1 & 1 & 0.9778 & 0.6657 & 0.651 & 0.651 \\
\hline 2009 & 1.5446 & 8.834 & 0.1749 & 1 & 1 & 1 & 0.1749 & 0.1749 & 1 & 1 & 1 & 0.1749 & 0.1749 & 0.1749 \\
\hline 2010 & 1.3655 & 1.9999 & 0.6828 & 1 & 1 & 1 & 0.6828 & 0.6828 & 1 & 1 & 1 & 0.6828 & 0.6828 & 0.6828 \\
\hline 2010 & 1.2307 & 1.8635 & 0.6604 & 1 & 1 & 1 & 0.6604 & 0.6604 & 1 & 1 & 1 & 0.6604 & 0.6604 & 0.6604 \\
\hline 2010 & 1.1606 & 1.6902 & 0.6867 & 1 & 1 & 1 & 0.6867 & 0.6867 & 1 & 1 & 1 & 0.6867 & 0.6867 & 0.6867 \\
\hline 2010 & 1.4737 & 2.8864 & 0.5106 & 1 & 1 & 0.9443 & 0.5406 & 0.5106 & 1 & 1 & 1 & 0.5106 & 0.5106 & 0.5106 \\
\hline 2011 & 1.2318 & 1.2595 & 0.978 & 1 & 1 & 1 & 0.978 & 0.978 & 1 & 1 & 1 & 0.978 & 0.978 & 0.978 \\
\hline 2011 & 1.1205 & 1.8365 & 0.6101 & 1 & 1 & 0.9944 & 0.6136 & 0.6101 & 1 & 1 & 1 & 0.6101 & 0.6101 & 0.6101 \\
\hline 2011 & 1.1683 & 1.9933 & 0.5861 & 1 & 1 & 1 & 0.5861 & 0.5861 & 1 & 1 & 1 & 0.5861 & 0.5861 & 0.5861 \\
\hline 2011 & 1.3548 & 2.7049 & 0.5009 & 1 & 1 & 1 & 0.5009 & 0.5009 & 1 & 1 & 1 & 0.5009 & 0.5009 & 0.5009 \\
\hline 2012 & 1.1038 & 1.2343 & 0.8942 & 1 & 1 & 1 & 0.8942 & 0.8942 & 1 & 1 & 0.9826 & 0.9101 & 0.8942 & 0.8942 \\
\hline 2012 & 1.1535 & 1.4072 & 0.8197 & 1 & 1 & 0.9972 & 0.822 & 0.8197 & 1 & 1 & 1 & 0.8197 & 0.8197 & 0.8197 \\
\hline 2012 & 1.1106 & 1.3793 & 0.8052 & 1 & 1 & 1 & 0.8052 & 0.8052 & 1 & 1 & 1 & 0.8052 & 0.8052 & 0.8052 \\
\hline 2012 & 1.177 & 2.0195 & 0.5828 & 1 & 1 & 1 & 0.5828 & 0.5828 & 1 & 1 & 1 & 0.5828 & 0.5828 & 0.5828 \\
\hline MEAN & 1.2642 & 2.3603 & .6788 & .9997 & .9972 & .9974 & .6806 & .6790 & .9987 & .9982 & .9918 & .6865 & .6798 & .6812 \\
\hline
\end{tabular}


Table 6: Changes in Productivity and Efficiency

Hicks-Moorsteen Indexes Comparing Firm $i$ in Period $t$ with Firm i in Period $t$ - 1

\begin{tabular}{|c|c|c|c|c|c|c|c|c|c|c|c|c|c|c|}
\hline \multicolumn{15}{|c|}{ Hicks-Moorsteen Indexes Comparing Firm $i$ in Period $t$ with Firm i in Period $t-1$} \\
\hline Period & dTFP & dTech & dTFPE & dOTE & dOSE & dOME & dROSE & dOSME & dITE & dISE & dIME & dRISE & dISME & dRME \\
\hline 2005 & 1.1338 & 0.9381 & 1.2086 & 1 & 1 & 1 & 1.2086 & 1.2086 & 1 & 1 & 1 & 1.2086 & 1.2086 & 1.2086 \\
\hline 2005 & 1.0349 & 1.0861 & 0.9529 & 1 & 1 & 1 & 0.9529 & 0.9529 & 1 & 1 & 0.9908 & 0.9617 & 0.9529 & 0.9529 \\
\hline 2005 & 1.2665 & 0.9381 & 1.35 & 1 & 1 & 1.0717 & 1.2597 & 1.35 & 1 & 1 & 1.0362 & 1.3028 & 1.35 & 1.35 \\
\hline 2005 & 1.0005 & 0.9381 & 1.0664 & 1 & 1 & 1 & 1.0664 & 1.0664 & 1 & 1 & 1 & 1.0664 & 1.0664 & 1.0664 \\
\hline 2006 & 1.0984 & 1.063 & 1.0333 & 1 & 1 & 1 & 1.0333 & 1.0333 & 1 & 1 & 1 & 1.0333 & 1.0333 & 1.0333 \\
\hline 2006 & 1.1157 & 1.0789 & 1.0341 & 1 & 1 & 1 & 1.0341 & 1.0341 & 1 & 1 & 1 & 1.0341 & 1.0341 & 1.0341 \\
\hline 2006 & 1.0313 & 1.0255 & 1.0056 & 1 & 0.9666 & 1 & 1.0056 & 1.0056 & 1 & 0.9666 & 1 & 1.0056 & 1.0056 & 1.0404 \\
\hline 2006 & 1.0995 & 1.0476 & 1.0495 & 1 & 1 & 1 & 1.0495 & 1.0495 & 1 & 1 & 1 & 1.0495 & 1.0495 & 1.0495 \\
\hline 2007 & 1.0744 & 1.0015 & 1.0727 & 1 & 1 & 1 & 1.0727 & 1.0727 & 1 & 1 & 1 & 1.0727 & 1.0727 & 1.0727 \\
\hline 2007 & 0.9863 & 0.9287 & 1.0621 & 1 & 1 & 1 & 1.0621 & 1.0621 & 1 & 1 & 1 & 1.0621 & 1.0621 & 1.0621 \\
\hline 2007 & 1.0988 & 0.9617 & 1.1425 & 1 & 1.0346 & 1 & 1.1425 & 1.1425 & 1 & 1.0346 & 1.0314 & 1.1078 & 1.1425 & 1.1043 \\
\hline 2007 & 0.9233 & 0.8326 & 1.109 & 1 & 1 & 1 & 1.109 & 1.109 & 1 & 1 & 1 & 1.109 & 1.109 & 1.109 \\
\hline 2008 & 1.1753 & 1.2924 & 0.9094 & 1 & 1 & 1 & 0.9094 & 0.9094 & 1 & 1 & 1 & 0.9094 & 0.9094 & 0.9094 \\
\hline 2008 & 0.8463 & 1.2026 & 0.7037 & 1 & 1 & 1 & 0.7037 & 0.7037 & 1 & 1 & 1.0032 & 0.7015 & 0.7037 & 0.7037 \\
\hline 2008 & 1.0557 & 1.1098 & 0.9513 & 1 & 1 & 1 & 0.9513 & 0.9513 & 1 & 1 & 1 & 0.9513 & 0.9513 & 0.9513 \\
\hline 2008 & 0.7656 & 1.2561 & 0.6095 & 1 & 1 & 1 & 0.6095 & 0.6095 & 1 & 1 & 1 & 0.6095 & 0.6095 & 0.6095 \\
\hline 2009 & 0.7666 & 0.5735 & 1.3368 & 1 & 1 & 1 & 1.3368 & 1.3368 & 1 & 1 & 1 & 1.3368 & 1.3368 & 1.3368 \\
\hline 2009 & 0.8313 & 0.7772 & 1.0696 & 0.9913 & 0.9447 & 0.9796 & 1.1015 & 1.0791 & 0.9583 & 0.9772 & 0.8953 & 1.2468 & 1.1162 & 1.1423 \\
\hline 2009 & 0.8644 & 0.6941 & 1.2454 & 1 & 1 & 1 & 1.2454 & 1.2454 & 1 & 1 & 0.9778 & 1.2736 & 1.2454 & 1.2454 \\
\hline 2009 & 0.7293 & 0.5735 & 1.2716 & 1 & 1 & 1 & 1.2716 & 1.2716 & 1 & 1 & 1 & 1.2716 & 1.2716 & 1.2716 \\
\hline 2010 & 0.6828 & 0.5 & 1.3655 & 1 & 1 & 1 & 1.3655 & 1.3655 & 1 & 1 & 1 & 1.3655 & 1.3655 & 1.3655 \\
\hline 2010 & 0.9361 & 0.7068 & 1.3245 & 1.0088 & 1.0586 & 1.0982 & 1.1956 & 1.3129 & 1.0435 & 1.0234 & 1.0188 & 1.2458 & 1.2693 & 1.2403 \\
\hline 2010 & 0.902 & 0.8876 & 1.0163 & 1 & 1 & 1 & 1.0163 & 1.0163 & 1 & 1 & 1 & 1.0163 & 1.0163 & 1.0163 \\
\hline 2010 & 0.7334 & 0.579 & 1.2668 & 1 & 1 & 0.9443 & 1.3415 & 1.2668 & 1 & 1 & 1 & 1.2668 & 1.2668 & 1.2668 \\
\hline 2011 & 1.0225 & 0.8678 & 1.1783 & 1 & 1 & 1 & 1.1783 & 1.1783 & 1 & 1 & 1 & 1.1783 & 1.1783 & 1.1783 \\
\hline 2011 & 1.0525 & 1.1626 & 0.9053 & 1 & 1 & 0.9944 & 0.9104 & 0.9053 & 1 & 1 & 1 & 0.9053 & 0.9053 & 0.9053 \\
\hline 2011 & 0.9904 & 1.126 & 0.8795 & 1 & 1 & 1 & 0.8795 & 0.8795 & 1 & 1 & 1 & 0.8795 & 0.8795 & 0.8795 \\
\hline 2011 & 1.1536 & 1.1341 & 1.0172 & 1 & 1 & 1 & 1.0172 & 1.0172 & 1 & 1 & 1 & 1.0172 & 1.0172 & 1.0172 \\
\hline 2012 & 0.9471 & 0.8629 & 1.0976 & 1 & 1 & 1 & 1.0976 & 1.0976 & 1 & 1 & 0.9826 & 1.1171 & 1.0976 & 1.0976 \\
\hline 2012 & 0.9954 & 0.9113 & 1.0922 & 1 & 1 & 0.9972 & 1.0953 & 1.0922 & 1 & 1 & 1 & 1.0922 & 1.0922 & 1.0922 \\
\hline 2012 & 1.0677 & 0.9901 & 1.0784 & 1 & 1 & 1 & 1.0784 & 1.0784 & 1 & 1 & 1 & 1.0784 & 1.0784 & 1.0784 \\
\hline 2012 & 1.1081 & 0.8889 & 1.2466 & 1 & 1 & 1 & 1.2466 & 1.2466 & 1 & 1 & 1 & 1.2466 & 1.2466 & 1.2466 \\
\hline MEAN & .9840 & .9355 & 1.0829 & 1.0000 & 1.0001 & 1.0027 & 1.0796 & 1.0828 & 1.0001 & 1.0001 & .9980 & 1.0851 & 1.0826 & 1.0824 \\
\hline
\end{tabular}


NOTES 